\title{
44
}

\section{Strengthening Australian Legal Ethics and Professionalism}

\author{
Adrian Evans ${ }^{\dagger}$
}

\section{Introduction}

Initiatives designed to reform and strengthen legal professional ethics are obviously needed. While we are constantly exposed to courageous, justicecentred lawyers and judges, these individual examples of good lawyering are not the everyday reality of many peoples' encounters with the legal profession.

Consider other lawyers' continuing moral silence and diverse misconduct in the theft of client funds and habitual overcharging leading to constant appearances in courts and disciplinary tribunals; of in-house counsel with insufficient courage who overlook insider corruption in the Reserve Bank or AWB; of litigation lawyers who advise delay and obstruction as the preferred strategy of those Catholic bishops who have covered up priests' paedophilia; of over-zealous commercial lawyering which actively facilitates socially and environmentally destructive development in Queensland and PNG, not to mention routinely callous and discourteous lawyer-to-lawyer behaviours across the country. To cap it all off, the global controversy erupting from the millions of Panama Papers, leaked from a single law firm, clarifies that the international legal profession differs

1 Faculty of Law, Monash University. 
little from the local in its attempts to dignify tax evasion as tax avoidance. ${ }^{2}$ All of these point to an ethically challenged legal profession which (most unfortunately) established law associations (all voluntary groupings) can ill-afford to sufficiently acknowledge. And government is mostly silent on these problems, because there are very few attorneys-general or investigative commissioners who come from outside the profession. So the potential for institutional law reform designed to reduce misconduct and strengthen individual morality is very limited.

Nevertheless, if coincidentally there were a media campaign emerging from an egregious scandal, appropriate judicial or maverick politician leadership and some level of educational and professional consensus about the extent of current de-professionalism, then change might occur. Here are three achievable initiatives that might be pursued.

\section{Legal Ethics and Professionalism Education}

Addressing stronger legal ethics at the regulatory level will remain superficial and transitory without longer-term changes to legal education that strengthen wellbeing and develop justice-focused values in new graduates, ${ }^{3}$ especially in those who aspire to commercial legal practice. How can a new lawyer who, over four years or more, is consistently educated to maximise the short-term interests of corporate clients regardless of justice - and who is paid and offered promotion according to the energy of their immediate billing of those same clients - hope to avoid developing a fractured psychology? And how can they be reasonably expected to suddenly develop a concern for those adversely impacted by their clients' operations, be they aggressively growth-focused rather than sustainable, tax evading rather than tax paying, or even corrupt?

To undermine and, I suggest, appropriately subvert such ego-driven lawyering, there is an effective and achievable educational pedagogy, one which operates on law students' psyche before materialism can completely dominate. In-house, live client, poverty-law clinical legal education (CLE)

2 Mossack Fonseca may now be the most widely known law firm of all, for the wrong reasons. See $A B C$ News, 5 April 2016, www.abc.net.au/news/2016-04-05/why-the-panama-papers-mossackfonseca-leaks-really-matters/7300262.

3 See Vivien Holmes, “Giving Voice to Values”: Enhancing Students' Capacity to Cope with Ethical Challenges in Legal Practice’ (2015) 18(2) Legal Ethics 115. 
- which explicitly articulates a virtue ethics approach, rather than the normally dominant role morality or consequentialism - can become a mandatory part of every law degree, in the interests of redirecting law graduates towards the essential social value of legal professionalism a concern for justice. CLE is not some variant of scientology for lawyers. It is a powerful, globally accepted pedagogy that lacks only some law deans' political courage.

\section{A. In-house, live client, poverty law experience - not just simulation}

Legal clinics come in many sizes and shapes, but not all purported clinics will achieve for students a heartfelt desire for justice. The best of clinical legal education involves an in-house experience, in the sense that the law school rather than an external agency operates the clinical site. Law schools can generally focus on conscious teaching of a justice agenda more deliberately than an agency such as a law firm or government department. Similarly, clients need to be real ('live'), if their everyday hopes and predicaments are to affect students emotionally. And those predicaments are most acute when clients are truly in need, as opposed to small businesses seeking advice on for example, GST compliance. Simulation is important and can encourage identification with clients despairing of a lack of access to justice, but it excels at teaching skills, not the development of a deep and life-changing empathy.

\section{B. Virtue ethics - not dominant role morality or consequentialism}

The intellectual base to justice is often assumed in law schools, rather than analysed and taught. Justice is a quintessential moral concept, and in particular a virtue in the Aristotelian sense. Justice is one of a number of virtues that sit inside the framework of virtue ethics, as opposed to the other two much better known and competing frameworks of consequentialism and Kantianism. But legal ethics education typically concentrates on the latter two methodologies, in particular role morality or zealous advocacy, which is an applied Kantian category that is not directly concerned for justice except to the extent that it coincidentally aligns with a client's needs. 
Teaching of legal ethics with a justice focus must redirect its energy towards virtue ethics, if overall justice is to mean something more to future lawyers than what an individual client may desire or need.

\section{Enhancing Ethical Infrastructure}

The Uniform Law regulatory initiative covering NSW and Victoria is limping along towards a hoped-for national uniformity, but it is going so slowly that it risks attracting national disability insurance support. There are no real signs of a national leadership vision emerging from the Uniform Legal Services Council; no sense of urgency about, for example, reforming the profoundly inadequate continuing professional development system, the highly partisan conduct rules which allow a single law firm to act against a former client in the face of that client's utter objections, and no embarrassment about the way in which our law societies and regulators use clients' funds without their effective knowledge.

\section{A. Mickey-Mouse CPD}

Continuing Professional Development (CPD) when first introduced in the 1980s was deliberately minimal, in order to build a degree of practitioner confidence in the concept: 10 hours per annum per practitioner, no assessment, no requirement for or monitoring of competent delivery, no face-to-face attendance requirements and minimal enforcement. Only one hour per annum is required for legal ethics. ${ }^{4}$ Such a basic structure no longer represents a quality-driven framework, if the objective is to build a credible ethical infrastructure.

\section{B. Entrenching successive conflicts of interest}

There have been many criticisms of the Australian Solicitors Conduct Rules, ${ }^{5}$ but the most important concern the egregious sanctification of the practice of some major law firms when it comes to dealing with prior clients. The Rules, specifically r 10.2 , were heavily influenced by the large law firms' group (i.e. the 10-12 very large Australian law firms, many

4 See, for example, the Legal Profession Uniform Continuing Professional Development (Solicitors) Rules 2015, rr 8 and 9, www.legislation.nsw.gov.au/sessionalview/sessional/sr/2015-242.pdf.

5 See Legal Profession Uniform Law Australian Solicitors' Conduct Rules 2015, www.legislation.nsw. gov.au/viewtop/inforce/subordleg $+244+2015+\mathrm{cd}+0+\mathrm{N}$. 
of which are now global players) to permit a firm to ignore the loyalty those prior clients might have thought they were owed and allow them to act for a new client against them, regardless of the prior client's protest. ${ }^{6}$ This single provision does more than almost any other regulatory rule to establish that the real priority of the largest firms is one of business rather than fidelity, and that the justice agenda is not inherently a compelling call on their partners' time.

\section{Unconscionable use of interest earned on clients' trust moneys distorts the moral funding of regulation}

Unlike most other countries, Australia in effect forces many clients to unwittingly contribute from their trust moneys to the various activities which financially support the legal profession. Known generically as Interest on Lawyers Trust Accounts (IOLTA), each of legal regulation, legal aid, lawyers' own education and, ironically (given this conference), lawyers' systemic advocacy of law reform, are regular beneficiaries of such money. Clients can avoid this leakage if they know to insist that they be paid their interest, but if they are ignorant, as most are, the transfer happens silently in the background. Between \$50-100 million is diverted annually around Australia in this manner.

Efforts have been made in the past to propose a national conduct rule requiring practitioners to assess whether clients could obtain a net interest benefit from their own funds, but have been met with professional silence, presumably because of the significant conflict of interest faced by the law societies and regulators should they pursue such a conduct rule. In particular, societies and legal services commissioners would have to fund a greater proportion of regulatory expenses from lawyer levies, which is in fact what occurs in most other countries. ${ }^{7}$

It is time to redress a fundamentally unethical funding structure and establish a regulatory funding model that links percentage contributions by lawyers to the gross revenue (not taxable profit) of the firm, and eschews any connection to subsidies from IOLTA funds. And the question

6 The requirement for an Information Barrier in such situations is beside the point: the prior client is effectively told that its earlier relationship was a business deal only, not that of a fiduciary or confidant. 7 The only major exception is South Africa, which has long operated a trust account interest transfer scheme similar to Australian jurisdictions. 
remains: how is it ethical - and the act of a genuine fiduciary - to not advise and warn clients of this clandestine subsidy, or at least to give them the option of keeping what is already their own money?8

\section{The courage to regulate lawyers}

But this clear need for a stronger local ethical culture and uniform infrastructure across Australia is, to many eyes, of little significance in the face of legal practice globalisation, with its Uber-like 'new law' models that subcontract to lawyers everywhere and hide moral accountability for individual lawyers' performance inside global firms' corporate structures, if not cyberspace; structures into which regulators only hesitantly venture, and then only in response to the rare complaint that is not resolved quietly and internally by managing partners who will do almost anything to preserve those corporate reputations. Think of George Clooney in Michael Clayton, but do not think such a scenario is incredible.

Though they ought to do so, it will not be enough for the current nonUniform Law jurisdictions to simply adopt the apparently impressive compliance audit provisions of NSW and Victoria. Former Queensland Legal Services Commissioner (LSC) John Briton has provided a powerful analysis of the compliance audit powers, which only permit an LSC to audit where he or she has 'reasonable grounds' to do so. ${ }^{9}$ This seemingly innocuous limitation keeps the LSC relatively impotent, ${ }^{10}$ because he/she can rarely if ever enter a firm to check out a mere rumour or to explore an intuition; they will first need a formal complaint or a whistleblower.

Currently, regulators encountering exceptional circumstances, but who lack witnesses, must have the courage to decide that there are reasonable grounds for a compliance audit and go into the largest firms. Even then, there is no requirement for the existence of the audit to be made public. But that courage and that transparency are not yet on display. Transparency International or another well-regarded public interest or consumer guardian would have much to contribute in strengthening the Uniform Legal Services Council if invited to join by someone in authority.

8 See Adrian Evans, The History and Control of the Solicitors Guarantee Fund (Vic) and its Ethical Implications for the Legal Profession (LLM, by major thesis, Monash University, 1997).

9 Legal Profession Uniform Law Application Act 2014 (Vic) s 256.

10 John Briton, 'Between the Idea and the Reality Falls the Shadow', www.monash.edu/law/ centres/clars/news-events/anzlec5-sustainable-legal-ethics. 
Consider for instance the huge meltdown in the share price of our largest listed lawyer: Slater and Gordon. The firm lost $\$ 958$ million in market capitalisation in just six months, ${ }^{11}$ as a result of incorrect financial projections and perhaps bad luck, maintaining throughout that clients' interests were at no time compromised. ${ }^{12}$ The firm had only until the end of April 2016 to convince its bankers that it has sufficient cash flow from completed clients' files to fund, regardless of salaries, a net debt of $\$ 741 \mathrm{~m}$ within 12 months. ${ }^{13}$ It could easily be that the firms' clients were or are suffering even though debt repayments have now been successfully delayed, in the sense that major and continuing negative publicity about share price falls and unresolved class actions against the firm are prejudicing some clients' confidence in their individual lawyers and/or causing them to query case management decisions, particularly those concerning case settlements. ${ }^{14}$

Is there a link between Slater and Gordon's firm-wide financial decisions about projected earnings and its case management policy? We don't know, but the published accounts for the six months to December 2015 are enough of a public indicator that a compliance audit is needed, and we do not know that that has happened. If it has occurred, there has been no public announcement that the audit is complete and that the firm is in the clear. Suffice to say, law reform in ethical infrastructure is needed and, in the case of listed corporations that also want to be law firms, will need to provide for much greater investigative capacity and transparency than is currently permitted by the Uniform Law.

\section{Personal Ethical Accountability}

If ethical infrastructure can easily go further, then why not individual ethical accountability? It would be a central mistake to think it is enough to move on the institutional or systemic front, but not on the personal. I have suggested that the assessment of an individual lawyer's general morality -

11 Jonathan Shapiro, 'Slater and Gordon Recruit Jumps Ship as Stock Sinks to New Low', The Age, Business News, 29 March 2016, 21.

12 Ibid.

13 Ibid.

14 News Limited reported on 2 May 2016 that the firm had avoided corporate shame and restructured (delayed) its debt repayments by 2-3 years under a deal with its lead banker, Westpac, www.news.com.au/finance/business/breaking-news/slatergordon-lenders-nod-for-restructure/newsstory/b3ad8a69956a636359aa24895d24cd42. 
involving not just their understanding of 'lawyer types' and general moral methodologies, but also the strength of desirable psychological traits and attitudes such as the virtues of honesty, courage and integrity - ought to become mainstream as a part of strengthening the CPD process, not to mention the fundamental purpose of improving personal conduct. ${ }^{15}$

More specifically, what appears to be needed is the recognition that character-strengthening is likely to be the new parameter in enhancing professional ethics. Accordingly, general morality personal ethics education and qualitative assessment of character at set intervals after admission is called for.

These reforms are technically achievable, either voluntarily at the behest of individual law associations - who might take the view that it is better to get in first and manage the process from inside the profession - or compulsorily as a condition of annual licensing, at the direction of a future Uniform Legal Services Council.

The various technical options for assessing these qualities were recently canvassed in the UK, ${ }^{16}$ but no one inside the profession or within an Attorney-General's office has yet bitten the reform bullet. Why the hesitation? There remains a considerable and primitive suspicion among practising lawyers that psychology is essentially an occult enterprise, or has at least the potential to substantially impact on their decision-making. The former fear is regrettable, but the latter is partially correct. A lawyer who is assessed psychologically as part of their routine annual licensing, not because of some perceived mental health problem, but to measure for reasonable levels of integrity and social empathy, is arguably more likely to understand and connect with clients who are deserving of more justice than their bank accounts will run to. Such positive attitudes are likely to impact favourably on the decisions they make to run cases and increase access to justice. They may also begin to improve public perceptions of legal professional reputations. There are well-accepted psychological

15 See generally Adrian Evans, Assessing Lawyers' Ethics (Cambridge University Press, Melbourne, 2011).

16 Richard Moorhead, Victoria Hinchly, Christine Parker, David Kershaw and Soren Holm, Designing Ethics Indicators for Legal Services Provision, UCL Centre for Ethics and Law, Working Paper No. 1, 2012, papers.ssrn.com/sol3/papers.cfm?abstract_id=2159296. 
scales (personal attribute inventories and psychological inventory questionnaires) that have been developed to measure, among many other things, an individual's degree of honesty and integrity. ${ }^{17}$

Professional integrity is a key social good that the legal profession can use not just to improve overall conduct and reputation, but to sustain lawyers' relevance in a modern technologically-infatuated business world. There is in fact no in-principle reason why a lawyer's measured levels of or capacity for integrity would not attract professional acceptance as a valueadd mechanism, if some of the latest predictions for removing lawyers from lucrative transactional work altogether came to fruition. Think for example, of the emerging Blockchain technology, which the major banks at least consider capable of establishing (among several other lawyerexcluding apps) an encrypted binary equivalent of the old 'chain of title' so important in the conveyance of general law land. ${ }^{18}$

In the face of continuing major ethics failures among lawyers, there is a tangible prospect of improved conduct as a result of heightened awareness by practitioners of their own 'integrity ranking', and of the marketing opportunity offered by such rankings. There will be fears about privacy and state control of lawyers, but these are arguments that are already essentially lost in the Australian context, and becoming historical only. ${ }^{19}$

\section{Conclusion}

I suggest that each of the above suggestions in legal professional regulation be undertaken as a matter of urgency by government in the interests of a reimagined ethical role for lawyers in contributing to a sustainable $21^{\text {st }}$ century society.

17 A well-known example of such an instrument is the Minnesota Multiphasic Personality Inventory. See www.verywell.com/what-is-the-minnesota-multiphasic-personality-inventory-2795582.

18 See Fabian Horton, 'Chain Reaction' (2016) 90(4) Law Institute Journal 69. If the true 'value add' of a lawyer to a standardised contract is his/her integrity, and that integrity is measured, then the active insertion of the lawyer into that transaction, despite the purported Blockchain guarantee, could add to the client's overall satisfaction by offering an additional level of safety, in the face of what will be inevitable efforts to hack the chains of code and expose the transaction to fraud.

19 WikiLeaks and its investigative imitators have established that broad scale electronic surveillance of all sorts is pervasive. In relation to State control of lawyers, the Uniform Legal Services Council is undoubtedly a creature of government, albeit comprising a majority of lawyers among its members. 
This text is taken from New Directions for Law in Australia: Essays in Contemporary Law Reform, edited by Ron Levy, Molly O’Brien, Simon Rice, Pauline Ridge and Margaret Thornton, published 2017 by ANU Press, The Australian National University, Canberra, Australia. 